九州大学学術情報リポジトリ

Kyushu University Institutional Repository

\title{
Modifying the Feed-in Tariff System in Japan : An Environmental Perspective
}

Hanada, Takanori

Department of Applied Science for Electronics and Materials, Interdisciplinary Graduate School of Engineering Sciences, Kyushu University

https://doi.org/10.5109/1800872

出版情報: Evergreen. 3 (2)，pp.54-58，2016-09. Green Asia Education Center バージョン：

権利関係 : 


\title{
Modifying the Feed-in Tariff System in Japan: An Environmental Perspective
}

\author{
Takanori Hanada* \\ Department of Applied Science for Electronics and Materials, \\ Interdisciplinary Graduate School of Engineering Sciences, Kyushu University, Japan
}

*Author to whom correspondence should be addressed, E-mail: takanori_hanada@kyudai.jp

(Received August 2, 2016; accepted September 21, 2016).

\begin{abstract}
The uptake of solar cell technology has been accelerated by feed-in tariff (FIT), a policy mechanism that requires electricity companies to purchase renewable energy at a certain price. A FIT system promotes solar cell technology in an economically rational manner. Currently, the crystalline silicon solar cell is the mainstream solar cell technology. However, we consider that this is not necessarily the best selection with regard to environmental protection. Path dependency explains how a set of decisions for any given circumstance is limited by the decisions made in the past, even though past circumstances may no longer be relevant. In this study, we investigate the path dependency of mainstream solar cell technology. We propose a redesign of the FIT system in order to promote environmentally friendly solar cells in terms of energy and resource saving at the manufacturing stage, both of which contribute to the prevention of global warming.
\end{abstract}

Keywords: Feed-in Tariff, Path Dependency, Solar Cell, Renewable Energy

\section{Introduction}

Renewable energy is generally defined as energy derived from energy resources that are naturally replenished within the human timescale, such as sunlight, wind, rain, tides, waves, and geothermal heat ${ }^{1)}$. Since the introduction of a feed-in tariff (FIT) system in Japan in 2012, solar cell technology has attracted the most attention as a renewable energy technology, leading to a rapid increase in its penetration rate. While the levels of production and installation of solar cell technology in Japan were initially noteworthy, globally, they now occupy the 3rd or 4th position. In addition, the price of solar cell technology used in solar power generation systems has fallen precipitously. Currently, crystalline silicon solar cells constitute the mainstream technology for solar cells. Using the concept of path dependency, this paper explains why this technology is not necessarily the best selection in terms of environmental protection. Path dependency describes how a set of decisions for any given circumstance is limited by the decisions made in the past, even though past circumstances may no longer be relevant ${ }^{2}$. In other words, the selection of technology is predetermined by extrinsic past circumstances. Namely, the technology the product should be equipped with is selected by external circumstances driven by social, technical, and economic factors, rather than deterministic criteria $^{3)}$.

As an example of path dependency, consider a keyboard layout and the power source of automobiles in the United States in the early 1900s. Currently, the QWERTY keyboard layout is the most popular. However, it was originally designed to purposely slow down the typing speed to around 1900. The Dvorak layout was designed to replace the QWERTY keyboard layout in the belief that it would significantly increase typing speeds compared to the QWERTY layout. The latter is used even now, because users who have already mastered typing in this layout avoided the switching costs involved with the conversion to the DVORAK layout. In another example, consider the early 1900s, when three types of vehicles existed in the United States: the steam car, gasoline car, and electric vehicles. Each technical improvement had been promoted. However, the transportation of water needed for the steam engines to function was hampered by the epidemic that affected horses, and subsequently, Ford Motor Company built a mass production system for gasoline automobiles, namely, the Ford Model T. These advantages fueled the rise of gasoline vehicles and were determined by the above-mentioned events ${ }^{4}$. These are examples of how social factors such as resistance to learning new technology and the equine epidemic acted as determining factors in the uptake of future technology. If we think that the original purpose of the solar cell is not only to generate electrical energy from sunlight but also to contribute to global environmental conservation, we believe that the technology should be selected in accordance with the amount of energy consumed during its manufacture as well as the raw materials used in its 
production. However, it can be said that, currently, mainstream technology is selected depending on the economic aspect only. In other words, the technology in which the pork barrel is the easiest way for the user and make was selected by FIT system. In this study, we refer to the drop in the price of the solar cell, and considering the social, technical, and economic viewpoints, we discuss the factors that influence the selection of solar cell technology and its path dependency. We propose the redesign of the FIT system as per environmental factors, namely, energy and resource saving at the manufacturing stage, mainly as a contribution to the prevention of global warming.

\section{Feed-in Tariff}

FIT is a policy that obligates an electric power company to buy the electricity generated from renewable energy sources such as sunlight, wind power, hydropower, geothermal energy, and biomass energy at a predetermined fixed price. Although the idea of this policy originated in Germany, it has been introduced in France, Italy, Spain, and other countries around the world. In Japan, the bill allowing FIT was submitted in April 2014, immediately after the Great East Japan Earthquake, and it was approved unanimously in both houses of the Diet. Although an electric power company should mandatorily buy the electricity generated from renewable energy sources, it is not necessary for the company to bear the fee, which came to be added to the price of electric power charged to consumers as the "renewable energy tariff." Because the electric power companies must buy the electricity despite having an oversupply of electricity, renewable energy generation has become a profitable business model. In other words, the logic of the FIT system is based on the economic rationale that companies are bound to participate in the large-scale power generation business.

The amount paid for the installation of the solar cells is added to the electricity price for general households, and the business operator earns the tariff; the FIT mechanism is such that as the technology spreads, the price of electricity rises. However, the burden of increases electricity charges is borne by the consumer. The European countries, where the FIT system was first introduced, face the problem of an overall rise in electricity prices. Under the current FIT system, new power generation operators are only required to invest vast amounts in the technology set-up and are able to profit easily without conducting fresh research and development. This unexpected situation is diametrically opposite the original intention of the policy; as a result, technological developments in the renewable energy field have come to a halt. In Japan, each power company has taken measures to stop purchasing power before the rise in the electricity price becomes significant, and thus, skyrocketing electricity rates have yet to be reported. However, the consumers disapprove of the rise in prices and are of the view that they are caused by the electric power companies, which tend to ensure that their businesses are "always profitable" as they have made large-scale investments in the same.

\section{Path dependency of solar cell technology}

When many of the solar cell manufacturers overseas went bankrupt, low price competition due to the commoditization of solar cell technology was thought to be the reason for the same. We define as the difficulty in differentiating a product produced by many companies owing to its widespread generalization ${ }^{5)}$. As the solar cell became increasingly commoditized, it became difficult to differentiate a cell produced by one company from that manufactured by other companies, and thus, prices fell owing to the competition. The crystalline silicon solar cell became the mainstream solar cell technology. In this paper, we investigate the driving factors that lead to the eventual selection of the crystalline silicon solar cell as the mainstream technology from the viewpoint of path dependency.

\subsection{Customer value of solar cell technology}

The thin-type three-dimensional (3D) television (TV) used to be popular but has fallen out of fashion now. Although previously this product may have been perceived as an improvement over the conventional TV display, it did not match the market needs ${ }^{6}$. Thus, if some added value is introduced in a product in order to improve its function, it can become increasingly difficult to differentiate it from other products. "Customer value ceiling" has been suggested as the reason behind this phenomenon ${ }^{7}$. According to this idea, customers are not willing to pay for a commercial product although its technology may be superior, unless they perceive a value for this function.

In Japan's case, the solar cell's long-term reliability is believed to be its unique selling point ${ }^{8)}$. However, from the viewpoint of customer value, the purchasers of the technology are generally satisfied if sufficient power generation is assured in terms of actual daylight hours ${ }^{9)}$. Thus, it is difficult to differentiate among different types of solar cells, and we consider that the market drives the manufacturers to produce low-cost, and thus, mass-produced, solar cell technology.

\subsection{Modular type technology and its leakage}

Japan's industrial production enjoys the advantage of integral-type manufacturing ${ }^{10)}$. This manufacturing method produces high-performance and high-functioning products. Because foreign companies are not able to catch up easily with this technology, Japan's competitive advantage is likely to be maintained in the future. However, in recent years, other countries have caught up with the production of some technologies that were originally developed in Japan, such as the liquid crystal 
display (LCD) and DVD player. This lessens Japan's competitive advantage in the future and has been attributed to product modularization, namely, the manufacture of a product via a simple assembly line, owing to growing competition among lower-priced products.

Solar cells are easily assembled because each part in a solar cell is modularized. The structure of the solar cell includes a power generating unit (which is the cell or a thin film) placed on a glass substrate. The reverse side is sealed with a highly weather-resistant resin film, and the edge is capped with an aluminum frame. The integral-type technology is used to manufacture the components responsible for power generation. If developing nations catch up with the manufacture of the power generation component, they can also begin assembling and manufacturing solar cells independently. Indeed, some developing nations have acquired the ability to manufacture low-priced solar cells given the twin combination of low wages and a labor-intensive industry.

Thus, the know-how and human resources required in integral-type technology manufacturing are now common knowledge for other countries. For example, the adjustment technology of the LCD TV was originally devised and manufactured in Japan; however, the $\mathrm{S}$ Corporation co-signed Samsung Electronics of South Korea Samsung into manufacturing LCD TVs, and the manufacturing processes of several important technologies thus became known to another country. Subsequently, Samsung was able to manufacture large-sized TVs of better quality ${ }^{11)}$.

In the case of solar cell technology, the supply shortage of silicon solar cells was overcome after 2009 owing to the provision of the raw materials for silicon cells from China. Silicon ingot manufacturing technology is also an integral-type technology, but Japanese engineers provided technical guidance to China, causing the leakage of this technology know-how as well ${ }^{12)}$.

\subsection{Government support to developing nations}

Government support to developing nations is one reason for the price reduction of a product. The policies of the governments of South Korea and Taiwan caused companies to use state support, reduce their depreciation expenses, and easily purchase manufacturing equipment from Japan and western countries. As a result, the propagation velocities of some technologies, including solar cells, were accelerated, and these countries eventually became producers of high performance solar cells ${ }^{13)}$.

For emerging countries to acquire a competitive advantage in the global market, it is necessary that they realize cost reduction by labor-intensive production against the background of low wages. Expansion in scale with the enlargement of manufacturing facilities is also vital for companies to be able to take advantage of the latest techniques.

However, government support is believed to have led to the overcapacity in the manufacture of solar panels as well as solar cells by Chinese companies. Currently, the production capacity of solar cells by Chinese domestic enterprises stands at $35 \mathrm{GW}$. Despite possessing such a production capacity, only $20.1 \mathrm{GW}$ of electricity was produced beyond the $29 \mathrm{GW}$ of global solar cell demand in 2013. Suntech Power Co. declared bankruptcy because of such excessive capital investment.

\section{Present-day solar cell technology}

Solar cells are classified into silicon-based solar cells, which use silicon as the raw material, and compound-based solar cells, which employ elements such as cadmium, tellurium and copper, or indium and selenium. The other types of solar cells are organic solar cells and dye-sensitized solar cells. However, these cells are currently still at the development stage. A comparison of the constituent elements of various solar cells indicates that silicon has an advantage, as it is a resource with an abundant and stable supply in contrast to the other elements.

\subsection{Conversion efficiency of different types of solar cells}

Conversion efficiency refers to the efficiency of conversion of solar energy into electric energy by a solar cell. Typically, solar cells consist mainly of silicon. Several types of solar cells use single-crystal, polycrystalline, and thin-film (amorphous) silicon. The efficiencies of a typical single-crystal, polycrystalline, and thin-film silicon solar cell are $20 \%, 15 \%$, and $10 \%$, respectively. On the other hand, the efficiencies of CIS-based solar cells, which consist mainly of copper and indium, and of CdTe-based solar cells comprising cadmium and tellurium are $12 \%$ and $11 \%$, respectively. Several manufacturers have produced a solar cell with higher efficiency by combining the thin-film and crystalline silicon cells.

\subsection{Environmental characteristics of solar cells}

A comparison among the various kinds of solar cells indicates that environmentally friendly solar cells tend to be energy- and resource-saving (the latter, in terms of the amount of raw materials needed to manufacture the solar cells, and the former, in terms of the low energy required for their production). The amounts of raw materials needed in solar cells depend on their thicknesses; the thickness of a crystalline silicon solar cell is 100 200 $\mu \mathrm{m}$ while that of a thin-film silicon solar cell is only about $1 \sim 2 \mu \mathrm{m}$. In addition, the thickness of the CIS-based solar cell is approximately $3 \mu \mathrm{m}$ and that of the CdTe solar cell is $3 \sim 7 \mu \mathrm{m}$. Therefore, with regard to raw material usage, thin-film silicon and compound-based solar cells have greater resource-saving potential.

Energy payback time is an indicator of the 
environmental performance of a solar cell in terms of energy. Energy payback time is a numerical value of the time taken for a solar cell to produce all the energy it uses in its life cycle. The energy payback times of a single-crystalline silicon cell, multi-crystalline silicon cell, thin-film silicon cell, and CIS-based solar cell are 3.0, 2.2, 1.75 and 1.4 years, respectively ${ }^{14)}$. Thus, from the point of view of energy usage, thin-film silicon solar cells and compound-based solar cells are preferred over the others.

\section{Conclusion}

Using the concept of path dependency, we discussed the factors driving the choice of one solar cell technology over another. We investigated the reason behind the emergence of crystalline silicon solar cells becoming the mainstream solar cell technology, namely, aggressive competition to manufacture and sell lower priced solar cells. We showed that the social factor of economic rationality plays a vital role in the market because the solar cell is essentially a product experiencing increasing commoditization. In terms of technical factors, the solar cell is a modular-type product, and new emerging manufacturers at the country level have caught up with the integral-type manufacturing technology, which used to be inherent to Japan alone. In economic terms, the low-cost solar cells produced using the present techniques are now manufactured abundantly, aided by the introduction of integral-type technology processes and cheaper labor costs in other countries. Another social factor pertains to the active support provided by the government in strengthening the competitiveness and superiority of the manufacturing industry in the global market. The FIT system justifies the economic rationality, making the price of the cell the primary selection criteria for the choice of the mainstream technology; thus, the uniqueness and added value of the product have been diluted considerably in the market. Furthermore, the government gives preferential treatment to strengthen domestic companies, which tend to acquire the most profitable technology and use the assets (manufacturing equipment and technology) available to them without conducting fresh research and development. Thus, we showed that, currently, crystalline silicon solar cells are the mainstream solar cell technology owing to their low cost and stable supply.

We also reviewed the environmentally friendly quotient of solar cells in terms of their contribution to global warming prevention via energy saving and resource conservation during the production process. Environmentally friendly solar cells need to realize lower energy payback times and use less amounts of raw materials. However, such cells are yet to replace crystalline silicon solar cells as the mainstream technology. Interestingly, the FIT system was introduced as a policy to disseminate solar power use and improve environmental protection. However, despite this intention, it has become a dissemination policy subject to economic rationality. We therefore propose that the FIT system be redesigned in order to promote the use of environmentally friendly solar cells rather than focusing on economic factors. Accordingly, we suggest a new policy that can provide incentives via subsidies or environmental labeling to solar cell technologies possessing an environmental advantage. Under the current FIT system, new power generation operators only need to make large-scale investments in the technology, which allow them to make profits easily without financing any new research and development. This has been an unintended outcome of the FIT system; the policy was devised carelessly and technological development in renewable energy has virtually stopped. We recommend renewing efforts in research and development in solar cell technology, as doing so is essential to identify avenues for cost reduction and conversion efficiency improvement.

\section{Acknowledgements}

The author would like to thank the authorities of the Advanced Graduate Program in Global Strategy for Green Asia for their support toward this research.

\section{References}

1) O. Ellabban, H. Abu-Rub, and F. Blaabjerg, "Renewable energy resources: Current status, future prospects and their enabling technology", Renew Sust E nerg Rev, 39, 748 (2014).

2) D. Praeger, "Our Love Of Sewers: A Lesson in Path Dependence", The P oop Culture Blog (2008).

3) A. Ishikawa, "The Path Dependency of Environmentally Conscious Products - The Mainstream Technology for Solar Cells", J Niigata U M anage, 20, 31 (2014).

4) E. Shu, "Analysis Visual Angle of Dominant Design Occurrence", Bull D ep Manage, Atomi U, 1, 85 (2003).

5) O. Naoto, "Marketing logic of Commoditization market", Yuhikaku Publishing, Japan, 1 (2007).

6) V. Savov, "It's official : 3D is dead", The Verge (2013). Retrieved from

http://www.theverge.com/2013/1/8/3852452/deathof-3d. Last accessed on June 132016.

7) K. Nobeoka, "Failure of Value Capture by Commoditization", RIETI Discussion Paper Series, p.13 (2006).

8) The Nikkei, "Durability Criteria for Solar Cell" (2013, March 29). 
9) H. Ozaki, "Intersection of Bankruptcy Suntech Power and Rollback of FIT", Nikkei Business ONLINE (2013). Retrieved from http://business.nikkeibp.co.jp/article/report/201303 22/245422/?P=1. Last accessed on June 132016.

10) T. Fujimoto, Capacity building competition — Why Japan's automobile industry is strong, Chuko Shinsho, Japan, 87 (2003).

11) Y. Tateishi, Goodbye! Our Sony, Bunshun Shinsho, Japan, 249 (2011).

12) H. Ozaki, "Five misconceptions of environmental businesses", Nikkei Premier Series, Japan, 124 (2011).

13) Kouichi Ogawa, "Repeating History of Decline", Nikkei Business, 57 (2012).

14) Mizuho Information \& Research Institute, "Surveys and Research on Life Cycle Evaluation of Solar Energy Power Generation System", NEDO Progress Report, Project No. 7015, 108 (2008). 